\title{
The Complexity of the Galileo Affair
}

\author{
Jesse Carson
}

On June 22, 1633 Galileo Galilei was found by the Roman Inquisition to be "vehemently suspected of heresy" for his defence of heliocentrism. ${ }^{1}$ Galileo's trial and the events surrounding it, commonly referred to as the 'Galileo affair', have often been used as examples of the inherent conflict between science and religion. Some consider the clash inevitable, and in light of the modern dispute between creationists and evolutionists, the history of the relationship becomes quite relevant. Though the Galileo affair may seem like one of the most obvious cases of religion supressing scientific progress, once one examines the historical context, a much more complex picture emerges. The events of June 22, 1633 are in fact a result of an intricate interplay of people, ideas and events over the course of multiple decades. This essay will attempt to demonstrate that complexity by examining some of the key factors of the Galileo affair. The reasons, both scientific and theological, for the Catholic Church's rejection of heliocentrism, will be examined. Two of the key characters, Pope Urban VIII and Galileo himself, will be placed in the historical context of the affair. Their personalities, in combination with important historical events such as the Protestant Reformation and the Council of Trent will help to show the wide range of factors that influenced the Galileo affair.

Although in recent decades historians have published a multitude of books, essays and articles criticising the simplistic view of the relationship between science and religion as a conflict, the tendency to discuss it in terms of a historical "war" is still very much in evidence. Gerald Weissmann, a research professor at New York University's School of Medicine, in his book Galileo's Gout, writes about what he terms the "Endarkenment", wherein religion is increasingly supressing and replacing science in our modern age. ${ }^{2}$ Though the religious/scientific situation of today is not the concern of this essay, Weissmann's introduction provides good examples of this deceptive war terminology. "The wars of religion are back" Weissmann claims. "For over a century in the lands of the West, the forces of faith and fact have largely observed an uneasy truce". He compares the Galileo affair to the modern conflict between evolutionism and creationism, disregarding the historical context of Galileo's encounter with the Church, and adding to the misconception of the Galileo affair as a battle between dogmatic churchmen and free-thinking scientists. ${ }^{5}$ Another book that helps to bring this popular misconception to light, though in a very different way, is Science VS. Religion by Elaine Howard Ecklund. Ecklund's book is a result of four years of research into the views on religion of modern day scientists. Between 2005 and 2008 Ecklund surveyed 1'700 scientists and interviewed 275 of them about their views on religion. ${ }^{6}$ Although her findings were largely positive, indicating that a necessary hostility between science and religion is largely an illusion, there were still some results that demonstrate a continued lack of understanding of the historical complexity of the Galileo affair.

\footnotetext{
${ }^{1}$ Maurice A. Finocchiaro, The Galileo Affair: A Documentary History (Berkeley and Los Angeles: University of California Press, 1989), 291.

${ }^{2}$ Gerald Weissmann, Galileo's Gout: Science in an Age of Endarkenment (New York: Bellevue Literary Press, 2007), 9 .

${ }^{3}$ Ibid.

${ }^{4}$ Ibid., 11.

${ }^{5}$ Ibid., 9.

${ }^{6}$ Elaine Howard Ecklund, Science VS. Religion: What Scientists Really Think (New York: Oxford University Press, 2010), 5 .
} 
Ecklund writes that the "conflict paradigm" was evident across all scientific disciplines, and some scientists alluded to the conflict between Galileo and the Catholic Church as evidence for the incompatibility of science and religion. ${ }^{7}$ Some even went as far as to reference the torture of Galileo as further evidence for incompatibility, an event that never actually happened, but remains as part of the misconception of the Galileo affair. ${ }^{8}$ Thus we can see that the view of the relationship between science and religion as a conflict, even a necessary one, is still very much in evidence, and the Galileo affair remains one of the key historical examples of the conflict. The examination of the specific historical circumstances surrounding Galileo's encounter with the Church will allow for a more fair view.

From the modern perspective the acceptance of heliocentrism over geocentrism may seem obvious. However, the sixteenth/seventeenth century perspective was much different. The acceptance of such a radical new idea would have required very powerful and conclusive evidence, evidence that Galileo did not have. Before examining some of the strongest objections to heliocentrism, something should be said about the hierarchy of the sciences in the seventeenth century. Mathematics and astronomy were considered to be quite low in the hierarchy, so when objections were raised to heliocentrism (rooted in mathematics and astronomy) based on the higher sciences the credibility of the theory was greatly reduced. Theology was considered preeminent amongst the sciences, often referred to as the 'Queen of the Sciences'. ${ }^{9}$ Thus, when theological objections were raised against heliocentrism, the preference was given to theology. There were also objections to heliocentrism based on physics. Copernicus's theory was rooted in mathematics, which was considered to be inferior to physics, so it was further discredited by the superior science. ${ }^{10}$

The reasons for rejecting heliocentrism came in two forms, scientific and theological. It is important to note that a clear distinction between science and theology would not have been made in the sixteenth and seventeenth centuries. Theology was included in the sciences, and was considered first amongst them. ${ }^{11}$ The scientific objections to heliocentrism came from physics as well as astronomy, and the majority of the objections from both rested on the absurdity of a moving earth. One of the strongest astronomical objections raised was the lack of an observable stellar parallax. If the earth were orbiting the Sun, then a shift in the position of the fixed sphere of the stars should be detectable. However, even Tycho Brahe, the great astronomical observer, could not detect any stellar parallax. Copernicus's answer to this was that the stars were such a great distance away that the parallax was not detectable. Tycho and many of his contemporaries considered the distance that would be necessary to obscure a stellar parallax to be ridiculously large and for this reason dismissed Copernicus's explanation. ${ }^{12}$ Although the lack of stellar parallax was definitely a valid argument against heliocentrism, it was not nearly of the same importance as the objections derived from physics, a science considered superior to astronomy. Isaac Newton's theory of universal gravitation, when it was popularized in the latter half of the

\footnotetext{
${ }^{7}$ Ecklund, Science VS. Religion, 19.

${ }^{8}$ Ibid., 149.

${ }^{9}$ Don O'Leary, Roman Catholicism and Modern Science: A History (New York: The Continuum International Publishing Group, 2006), xii.

${ }^{10}$ O'Leary, Catholicism and Science, xii.

${ }^{11}$ Finocchiaro, The Galileo Affair, 99.

12 Ann Blair, "Tycho Brahe's Critique of Copernicus and the Copernican System," Journal of the History of Ideas 51, no. 3 (1990): 364.
} 
seventeenth century, provided heliocentrism with a physical basis that greatly increased its credibility. ${ }^{13}$ At the time of Copernicus and Galileo, however, physics was dominated by Aristotelian thought, which was not compatible with heliocentrism. The physical laws of the Aristotelian system seemed to provide quite strong arguments against a moving earth. One objection pertained to the motion of light and heavy bodies. Aristotelians believed that heavy and light bodies would always return to their natural place of rest by means of the shortest distance possible (a straight line). If the earth were spinning on its axis, the path of a heavy body descending to the earth would be curvilinear and thus not the shortest possible distance. ${ }^{14}$ Another popular objection to heliocentrism was based on the Aristotelian principle that a body could only have one natural motion. Heliocentrism seemed to attribute the earth with three distinct natural motions, and was thus in direct violation of Aristotelian physics. ${ }^{15}$ There were many other objections based on Aristotelian physic (the motion of projectiles and the centrifugal force of a spinning earth, to name a few). ${ }^{16}$ As stated earlier, Newton's universal gravitation would eventually explain these apparent difficulties, but at the time that they were raised these were serious issues heliocentrism needed to deal with.

Though these scientific objections to heliocentrism were important, the main difficulties that the Catholic Church had with heliocentrism were theological. Although geocentrism was never established as official church doctrine, it was supported by scripture as well as the writings of the Church Fathers. ${ }^{17}$ There was a multitude of different verses in the Bible that were quoted in support of geocentrism. Two of the most popular ones were Ecclesiastes 1:5, "The Sun rises and the Sun goes down, and hastens to the place where it rises", and Joshua 10:12-13, wherein Joshua commands the Sun to stand still in the heavens to extend the day. ${ }^{18}$ The traditional interpretation of these scriptures was literal, meaning that it was the Sun that was in motion, not the earth. Another important factor to consider when examining the theological objections to heliocentrism is the way in which the physical sciences were seen in the sixteenth and seventeenth centuries. Both Catholic and Protestant theologians asserted that the true nature of the cosmos could not be determined with certainty through any amount of scientific study from a human beings perspective on earth. ${ }^{19}$ The true nature of the cosmos was something that only God could know, making the trust in Biblical passages over scientific hypotheses and the rejection of heliocentrism the logical path for the Church to take.

Regardless of the logic of the Church's decision to reject heliocentrism, the trial and condemnation of Galileo could be seen as an overly harsh response by religion to the threat of science. However, like the reasons for the rejection of heliocentrism, the reasons for the trial of Galileo in 1633 are much more complex than they have often been made out to be. The key event that spurred the harsh response of the Catholic Church to Galileo's defense of heliocentrism was Martin Luther's Protestant Reformation. The great split within the Catholic

\footnotetext{
${ }^{13}$ Edward Grant, "In Defense of the Earth's Centrality and Immobility: Scholastic Reaction to Copernicanism in the Seventeenth Century," Transactions of the American Philosophical Society, New Series 74, no. 4 (1984): 66-67.

14 Ibid., 40.

${ }^{15}$ Finocchiaro, The Galileo Affair, 23.

${ }^{16}$ Finocchiaro, The Galileo Affair, 20-22.

17 Lisa T. Sarasohn, "French Reaction to the Condemnation of Galileo, 1632-1642," The Catholic Historical Review 74, no. 1 (1988): 46.

${ }^{18}$ David C. Lindberg and Ronald L. Numbers, When Science and Christianity Meet (Chicago: University of Chicago Press, 2003), 48.

${ }^{19}$ O'Leary, Catholicism and Science, xiii.
} 
Church in the sixteenth century resulted in the Catholic Church losing half of Europe to Protestantism. The Church saw this loss as a result of a lack of unity and a relaxed treatment of dissent. $^{20}$ In response the Church shifted to be more centralized and authoritarian. This is exemplified in the policies that arose from the Council of Trent (1545-1563). The policy key to the Galileo affair pertains to the interpretation of scripture (exegesis). The Protestant view of exegesis emphasized personal interpretation and the openness of scriptural meaning. Partially in response to this, and partially due to a desire for increased centrality and authority, the Council of Trent declared that interpretation of scripture was the realm of the holy Fathers and the Catholic authorities alone. ${ }^{21}$ This would be key to the harsh response of the Church to Galileo.

In 1613, Galileo wrote a letter to Benedetto Castelli, a supporter of heliocentrism, advising him on how to defend heliocentrism against scriptural objections. In his letter Galileo argues that the verses in the Bible that seem to oppose heliocentrism were phrased in that way to appeal to the common people of the time. ${ }^{22}$ Here Galileo is acting in complete opposition to the decrees of the Council of Trent. He, a mathematician, is attempting to do his own exegesis to make scripture fit with his scientific beliefs. It is this attempt at personal interpretation of scripture that first gets Galileo into trouble with the Inquisition, not his scientific beliefs. The letter to Castelli caused Galileo's initial encounter with the Inquisition, and the issuing of the precept against him on February 26, 1616. The precept prohibited Galileo from teaching, defending or treating heliocentrism in any way. ${ }^{23}$ This precept is important for understanding the specific events that resulted in Galileo being called to trial and charged with heresy in 1633.

After his warning and precept in 1616, Galileo remained largely silent, content to work on his Dialogue Concerning the Two Chief World Systems. However, when in 1630 Galileo sought permission from Niccolo Riccardi, the chief papal censor, to publish his Dialogue he failed to inform Riccardi about the precept of 1616. ${ }^{24}$ Galileo's trial in 1633 was sparked by the publication of the Dialogue, so it was partially his failure to inform the censor of the precept that caused him to be summoned to trial. The trial was called by Pope Urban VIII, a key personality in the Galileo affair. Urban calling Galileo to trial for publishing his Dialogue was by no means a necessary occurrence. Although he was undoubtedly motivated in part by the theological concerns with Galileo's book, Urban had other important considerations to make pertaining to the Catholic Church's relationship with the Protestants. Urban had recently come under attack by other figures in the Church. He had been accused of not committing enough resources to the Thirty Years War between the Catholics and the Protestants, and faced criticism for not declaring it a holy war. ${ }^{25}$ Galileo now provided Urban with an opportunity to demonstrate his authority and commitment to Catholicism by dealing decisively with the perceived threat to the authority of the Church. ${ }^{26}$ There was also a personal element to Urban's decision to send Galileo to the Inquisition. Simplicio, the character in Galileo's Dialogue who represents the traditional geocentric view, was seen by some to be a caricature of Urban because some of Urban's own

\footnotetext{
${ }^{20}$ Lindberg and Numbers, When Science and Christianity Meet, 45.

${ }^{21}$ Finocchiaro, The Galileo Affair, 12.

${ }^{22}$ Finocchiaro, The Galileo Affair, 50.

${ }^{23}$ Thomas F. Mayer, “The Roman Inquisition's precept to Galileo (1616)," The British Journal for the History of Science 43, no. 3 (2010): 328.

${ }^{24}$ Ibid.

${ }^{25}$ Finocchiaro, The Galileo Affair, 13.

${ }^{26}$ Ibid., 12.
} 
arguments were put into Simplicio's mouth. Because the character is defeated at every turn in the Dialogue, the possible connection between him and Urban required a response from Urban, to save face in light of the attacks already being made against him. ${ }^{27}$

The tendency to see the Galileo affair as a simple conflict or war between repressive theology and forward thinking science is happily on the decline As further studies are done, the true complexity of the event is coming to the forefront. This essay has been an attempt to demonstrate, at least in part, that complexity. Examining the reasons, both scientific and theological, for the Church's rejection of heliocentrism demonstrates that the Church may very well have been justified in rejecting such a revolutionary idea. The Inquisition was acting in line with the view of the majority (both theologically and scientifically) in the seventeenth century when it condemned heliocentrism. ${ }^{28}$ The reasons for the trials of Galileo and his eventual condemnation by the Inquisition were equally complex. They ranged far outside of science or theology. Galileo's condemnation was a result of specific personalities, including Pope Urban VIII and Galileo himself, in combination with certain historical events, namely the Protestant Reformation, Council of Trent and the Thirty Years War. As with any historical event, the full complexity of the Galileo affair will likely never be known. Thus it becomes crucial to always keep the wide range of factors that played into the affair in mind in an attempt to avoid dangerous generalizations such as the "conflict" between science and religion.

\section{Bibliography}

Blair, Ann. "Tycho Brahe's Critique of Copernicus and the Copernican System." Journal of the History of Ideas 51, no. 3 (1990): 355-377.

Ecklund, Elaine Howard. Science VS. Religion: What Scientists Really Think. New York: Oxford University Press, 2010.

Finocchiaro, Maurice A. The Galileo Affair: A Documentary History. Berkeley and Los Angeles: University of California Press, 1989.

Grant, Edward. "In Defense of the Earth's Centrality and Immobility: Scholastic Reaction to Copernicanism in the Seventeenth Century." Transactions of the American Philosophical Society. New Series 74, no. 4 (1984): 1-69.

Lindberg, David C., and Ronald L. Numbers. When Science and Christianity Meet. Chicago: University of Chicago Press, 2003.I

Mayer, Thomas F. "The Roman Inquisition's precept to Galileo (1616)." The British Journal for the History of Science 43, no. 3 (2010): 327-351.

O'Leary, Don. Roman Catholicism and Modern Science. New York: The Continuum International Publishing Group, 2006.

${ }^{27}$ Ibid., 13.

${ }^{28}$ O'Leary, Catholicism and Science, xiii. 
Sarasohn, Lisa T. "French Reaction to the Condemnation of Galileo." The Catholic Historical Review 74, no. 1 (1988): 34-54.

Weissmann, Gerald. Galileo's Gout: Science in an Age of Endarkenment. New York: Bellevue Literary Press, 2007. 